\title{
Characterization of Resistance to Six Chemical Classes of Site-Specific Fungicides Registered for Gray Mold Control on Strawberry in Spain
}

Dolores Fernández-Ortuño, Instituto de Hortofruticultura Subtropical y Mediterránea "La Mayora”-Universidad de Málaga-Consejo Superior de Investigaciones Científicas (IHSM-UMA-CSIC), Estación Experimental "La Mayora”, 29750 Algarrobo-Costa, Málaga, Spain; and IHSMUMA-CSIC, Dept. de Microbiología, Campus de Teatinos, 29071 Málaga, Spain; Juan Antonio Torés, IHSM-UMA-CSIC, Estación Experimental "La Mayora"; Manuel Chamorro, Instituto de Investigación y Formación Agraria y Pesquera (IFAPA), Consejería de Agricultura, Pesca y Desarrollo Rural, Junta de Andalucía, 41012 Seville, Spain; and Alejandro Pérez-García and Antonio de Vicente, IHSM-UMACSIC, Dept. de Microbiología, Campus de Teatinos

\begin{abstract}
Fernández-Ortuño, D., Torés, J. A., Chamorro, M., Pérez-García, A., and de Vicente, A. 2016. Characterization of resistance to six chemical classes of site-specific fungicides registered for gray mold control on strawberry in Spain. Plant Dis. 100:2234-2239.

Botrytis cinerea, causal agent of the gray mold disease, is one of the most economically important fungal pathogens of strawberry worldwide. In Spain, as in other parts of the world, management of gray mold control primarily involves the application of fungicides. To determine the fungicide resistance of the Spanish strawberry field population, 367 B. cinerea isolates were examined from one organic and 13 conventional strawberry fields in Huelva (Spain) in 2014 and 2015. The sensitivities of these isolates to six fungicides used for gray mold management in Spain were examined using a spore germination assay based on previously published discriminatory doses. The frequency of resistance to pyraclostrobin, boscalid, cyprodinil, fenhexamid, iprodione, and fludioxonil was 74.6, $64.8,37.0,23.7,14.7$, and $0.8 \%$, respectively. The majority of isolates

(35.1\%) were resistant to three different fungicides classes. Within these isolates, the most prevalent resistance profile $(55.8 \%)$ was resistance to pyraclostrobin, boscalid, and cyprodinil, followed by the resistance profile $(30.2 \%)$ of resistance to pyraclostrobin, boscalid, and fenhexamid. One isolate collected in 2015 was resistant to all six fungicide classes. Resistance to boscalid, fenhexamid, iprodione, and pyraclostrobin was found to be caused by amino acid substitutions on target proteins, including H272R/Y in SdhB, F412I/S/V in Erg27, I365 N/S in Bos1, and G143A in Cytb, respectively. The presence of multifungicide resistance phenotypes in B. cinerea isolates from strawberry fields in Spain must be considered in the development of future resistance management practices.
\end{abstract}

Strawberry (Fragaria $\times$ ananassa) is an important crop in Spain. In 2013, 8,000 ha were harvested and 312,500.00 tons of fruit were produced, making Spain the largest producer of fresh strawberry in Europe and the fourth largest producer worldwide (FAOSTAT; http://faostat3.fao.org/home/index.html). In Spain, more than $90 \%$ of the production takes place in the province of Huelva. This area has a Mediterranean climate, meaning that the summers are hot and dry, with long day lengths, and winters are wet and mild. Strawberry fruit are produced as an annual crop in this region. Strawberry production begins in June with land preparation and continues into July with field prep, followed by planting in the months of September and October. The harvest period occurs from February to May.

Challenges to strawberry include aphids (Aphis gossypii), lepidoptera (Helicoverpa armigera, Spodoptera littoralis, S. exigua and Chryxodeisis chalcites), mites (Tetranychus urticae), and numerous fungal diseases (Anonymous 2015). Among the fungal diseases, Botrytis cinerea Pers. is one of the most economically important pre- and postharvest pathogens, causing gray mold and crown rot of strawberry. The disease is initiated by conidia, which are produced on the dead tissue of overwintering plants (Jarvis 1977), and development is favored by prolonged periods of high humidity $(95 \%)$ and temperatures around $20^{\circ} \mathrm{C}$ (Bulger et al. 1987). Economic losses associated with gray mold are most pronounced during the cropgrowing season, postharvest, during storage, or during transit to commercial outlets (Jarvis 1977; Staats et al. 2005).

Corresponding author: D. Fernández-Ortuño;

E-mail: dfernandez-ortuno@uma.es

Accepted for publication 19 May 2016.

http://dx.doi.org/10.1094/PDIS-03-16-0280-RE

(C) 2016 The American Phytopathological Society
Gray mold management is primarily dependent on the application of site-specific fungicides during blooming and fruit maturation. Six chemical classes of these fungicides are used for gray mold management in Spain and include anilinopyrimidines (AP), dicarboximides (DC), keto-reductase inhibitors (KRI), phenylpyrroles (PP), quinone outside inhibitors (QoI), and succinate dehydrogenase inhibitors (SDHI). However, B. cinerea is considered a high-risk pathogen with regard to the propensity of fungicide resistance development (Fungicide Resistance Action Committee; www.frac.info) and, as a consequence, field isolates resistant to all of these site-specific fungicides were reported in different countries soon after their introduction (Bardas et al. 2010; Baroffio et al. 2003; Fernández-Ortuño et al. 2014).

$B$. cinerea isolates with multiple fungicide resistance are commonly found in vegetable crops in Spain; however, no comprehensive study of the occurrence, prevalence, or mechanisms of resistance, especially for the recently registered site-specific fungicides, has been conducted for any crop. In a study conducted in southeast Spain, fungicide resistance to methyl benzimidazole carbamates (MBC) and DC was commonly observed in $B$. cinerea isolates collected from cucumber, bean, tomato, squash, eggplant, and pepper (Raposo et al. 1996). In 2000, a follow-up study of 47 greenhouses of vegetable crops revealed that a high proportion of the $B$. cinerea population was resistant to DC, MBC, and N-phenylcarbamates. In a recent study from tomato greenhouses in the Canary Islands (Spain), B. cinerea isolates with resistance to carbendazim, iprodione, and pyrimethanil were recovered (Rodríguez et al. 2014). In strawberry, there has only been a single report of $B$. cinerea isolates resistant to $\mathrm{MBC}$, DC, and AP (Diánez et al. 2002).

Given the historic context of fungicide resistance in $B$. cinerea in Spain, monitoring of fungicide resistance in strawberry fields is important for revising management recommendations and developing resistance management strategies. In this study, strawberry fruit with $B$. cinerea were collected during spring 2014 and 2015 from commercial fields in Huelva (Spain). B. cinerea isolates were characterized 
for sensitivity to all classes of site-specific fungicides registered in Spain and examined for the presence of mutations in the target genes for each of the fungicide classes. The specific objectives were to assess the occurrence and distribution of the $B$. cinerea isolates with resistance to boscalid, cyprodinil, fenhexamid, fludioxonil, iprodione, and pyraclostrobin; to investigate the presence of multifungicideresistant $B$. cinerea isolates within field populations; and, finally, to determine the molecular mechanisms of resistance to DC, KRI, QoI, and SDHI.

\section{Materials and Methods}

B. cinerea isolates. In total, $367 \mathrm{~B}$. cinerea isolates were collected from 14 strawberry fields in Huelva (Table 1; Fig. 1). Single-spore isolations were performed as previously described (FernándezOrtuño et al. 2012). For long-term storage, each isolate was maintained as mycelium at $-20^{\circ} \mathrm{C}$ on a silica gel desiccated filter paper disc. To prepare spore suspensions, all of the isolates were grown on potato dextrose agar (PDA) in 90-mm-diameter petri dishes for 10 days at $22^{\circ} \mathrm{C}$ with a 14 -h photoperiod. Spores were harvested by flooding the dish surface with $2 \mathrm{ml}$ of sterile distilled water and pipetting the suspension gently off the dish surface, as previously described (Fernández-Ortuño et al. 2012). To remove any mycelium, spore suspensions were filtered through a $34-\mu \mathrm{m}$ nylon mesh and then adjusted to 2 to $4 \times 10^{5}$ conidia/ml for the in vitro assay.

Table 1. Origin and number of Botrytis cinerea isolates from commercial strawberry fields

\begin{tabular}{llrrr}
\hline & & \multicolumn{3}{c}{ Number of isolates } \\
\cline { 3 - 5 } Field code & & $\mathbf{2 0 1 4}$ & $\mathbf{2 0 1 5}$ & n total \\
\hline A & Moguer & 27 & 15 & 42 \\
B & Moguer & 24 & 12 & 36 \\
C & Lucena del Puerto & 29 & 0 & 29 \\
D & Almonte & 27 & 0 & 27 \\
E & Lepe & 25 & 25 & 50 \\
F & Almonte & 24 & 0 & 24 \\
G & La Redondela & 19 & 16 & 35 \\
H & Palos de la Frontera & 19 & 0 & 19 \\
I & Palos de la Frontera & 23 & 0 & 23 \\
J & Isla Cristina & 25 & 0 & 25 \\
K & Almonte & 0 & 25 & 25 \\
L & Almonte & 0 & 12 & 12 \\
M & Cartaya & 0 & 9 & 9 \\
N & San Bartolome de la Torre & 0 & 11 & 11 \\
Total & .. & 242 & 125 & 367 \\
\hline
\end{tabular}

In vitro fungicide sensitivity. In order to differentiate $B$. cinerea field isolates as sensitive (S), low resistant (LR), moderately resistant (MR), resistant (R), and highly resistant (HR), a spore germination assay with previously published discriminatory doses was used as described previously (Grabke et al. 2014; Li et al. 2014; Weber and Hahn 2011). The following fungicides were evaluated as formulated products: boscalid (Cantus; BASF Española S.A.); cyprodinil (Chorus; Syngenta España, S.A.); fenhexamid (Teldor; Bayer CropScience S.L.); fludioxonil (Scholar SC; Syngenta España, S.A.); iprodione (Rovral Aquaflo; BASF Española S.A.); and pyraclostrobin (Cabrio; BASF Española S.A.). Discriminatory concentrations of 1 and $50 \mu \mathrm{g} / \mathrm{ml}$ were used for boscalid in a $0.5 \%$ yeast extract agar (Weber and Hahn 2011). Cyprodinil ( 1 and $25 \mu \mathrm{g} / \mathrm{ml}$ ) was tested in a $0.5 \%$ sucrose agar (Weber and Hahn 2011). The active ingredients fenhexamid ( 1 and $50 \mu \mathrm{g} / \mathrm{ml}$ ), fludioxonil $(0.1$ and $10 \mu \mathrm{g} / \mathrm{ml})$, iprodione (5 and $50 \mu \mathrm{g} / \mathrm{ml})$, and pyraclostrobin $(0.1$ and $10 \mu \mathrm{g} / \mathrm{ml})$ plus the alternative oxidase inhibitor salicylhydroxamic acid at $100 \mu \mathrm{g} / \mathrm{ml}$ were evaluated in a $1 \%$ malt extract agar (Weber and Hahn 2011).

For each isolate and fungicide concentrations, a 40- $\mu$ l drop of the conidia suspension was streaked across the length of the corresponding medium. After 12 to $14 \mathrm{~h}$ (or $16 \mathrm{~h}$ in the case of cyprodinil and boscalid) of incubation at $22^{\circ} \mathrm{C}$, spore germination was evaluated under the microscope (OLYMPUS BX41TF; Olympus Optical Co. Ltd.) at $\times 40$ magnification as described previously (Weber and Hahn 2011). Isolate-fungicide combinations were conducted in triplicate for each isolate and the entirety of testing was performed twice.

DNA extraction, polymerase chain reaction amplification, and sequencing of four target genes. After isolates were incubated at $22^{\circ} \mathrm{C}$ on PDA for 3 days, genomic DNA was extracted as described previously (Chi et al. 2009). Genes cytochrome $b(c y t b)$ and the ironsulfur protein $(s d h B)$, the target genes of the QoI and SDHI fungicides, respectively, were amplified using the primer pairs and polymerase chain reaction (PCR) conditions previously described by Leroux et al. (2010). To investigate the nucleotide alterations at amino acid position 143 of Cytb, the amplification product was digested with the restriction enzyme FastDigest SatI (Thermo Scientific) using the manufacturer's instructions. The amplicons were sequenced when the digestion did not show the expected fragments. The bos 1 gene was amplified with the five primer pairs previously described by Ma et al. (2007) using the PCR conditions previously described by Grabke et al. (2014). Finally, the partial 3-keto reductase gene (erg27) was amplified and sequenced using the primer pairs and PCR conditions previously described by Grabke et al. (2013).

The PCR amplicons were analyzed on a 1 and $2 \%$ (for digested PCR products) agarose gel, stained with ethidium bromide, and visualized under UV-light. For sequence analysis, PCR products were

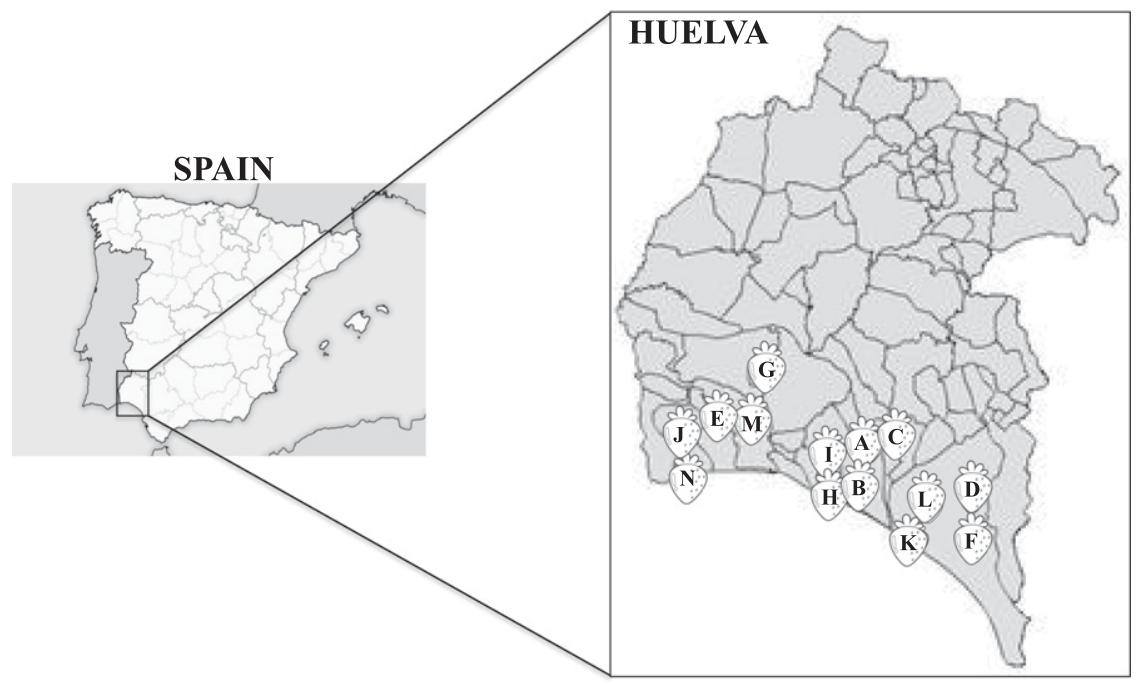

Fig. 1. Origin of Botrytis cinerea isolates used in this study. 
purified using the ExoSAP-IT PCR purification kit (USB Corporation), sequenced at Macrogen Europe, and analyzed using the DNASTAR sequence analysis software (DNASTAR, Inc.).

\section{Results}

Sensitivity of the isolates to boscalid, cyprodinil, fenhexamid, fludioxonil, iprodione, and pyraclostrobin. Of the 242 strawberry field isolates collected in 2014, $192(79 \%)$ were HR to pyraclostrobin, 173 (71\%) were R to boscalid, 72 (30\%) were MR and 24 (10\%) were R to cyprodinil, 57 (24\%) were HR to fenhexamid, and 43 (18\%) were LR to iprodione (Table 2). All 242 isolates were $\mathrm{S}$ to fludioxonil
(Table 2). Among the 125 field isolates collected in 2015, $82(66 \%)$ were HR to pyraclostrobin, $65(52 \%)$ were R to boscalid, 29 (23\%) and $11(9 \%)$ were MR and $\mathrm{R}$ to cyprodinil, respectively, and 30 (24\%) were HR to fenhexamid. On iprodione-amended medium, 10 $(8 \%)$ and $1(1 \%)$ of the isolates were LR and MR, respectively. Finally, $1(1 \%)$ and $2(2 \%)$ of the isolates were LR and MR, respectively, to fludioxonil (Table 2). All fungicide resistant phenotypes were confirmed in vivo on detached fruit sprayed with the formulated fungicides at recommended field rates (data not shown).

Resistance to pyraclostrobin, boscalid, and cyprodinil was found in isolates at every farm in the study (Table 2). Resistance to fenhexamid

Table 2. Number of fungicide-resistant isolates of Botrytis cinerea in Spain

\begin{tabular}{|c|c|c|c|c|c|c|c|c|c|c|}
\hline \multirow[b]{3}{*}{ Year, loc ${ }^{b}$} & \multirow[b]{3}{*}{$N^{\mathrm{c}}$} & \multicolumn{9}{|c|}{ Fungicide ${ }^{a}$} \\
\hline & & \multirow{2}{*}{$\frac{\text { Pyraclostrobin }}{\text { HR }}$} & \multirow{2}{*}{$\frac{\text { Boscalid }}{\mathbf{R}}$} & \multicolumn{2}{|c|}{ Cyprodinil } & \multirow{2}{*}{$\frac{\text { Fenhexamid }}{\text { HR }}$} & \multicolumn{2}{|c|}{ Iprodione } & \multicolumn{2}{|c|}{ Fludioxonil } \\
\hline & & & & MR & $\mathbf{R}$ & & LR & $\overline{M R}$ & $\overline{L R}$ & MR \\
\hline \multicolumn{11}{|l|}{2014} \\
\hline $\mathrm{A}$ & 27 & 9 & 8 & 5 & 2 & 4 & 1 & 0 & 0 & 0 \\
\hline B & 24 & 23 & 23 & 7 & 3 & 12 & 0 & 0 & 0 & 0 \\
\hline $\mathrm{C}$ & 29 & 27 & 19 & 6 & 3 & 5 & 4 & 0 & 0 & 0 \\
\hline $\mathrm{D}$ & 27 & 18 & 14 & 4 & 6 & 2 & 3 & 0 & 0 & 0 \\
\hline $\mathrm{E}$ & 25 & 22 & 20 & 9 & 1 & 7 & 2 & 0 & 0 & 0 \\
\hline $\mathrm{F}$ & 24 & 20 & 20 & 9 & 1 & 6 & 6 & 0 & 0 & 0 \\
\hline $\mathrm{G}$ & 19 & 16 & 13 & 3 & 0 & 14 & 3 & 0 & 0 & 0 \\
\hline $\mathrm{H}$ & 19 & 17 & 16 & 8 & 5 & 3 & 3 & 0 & 0 & 0 \\
\hline I & 23 & 16 & 16 & 7 & 1 & 3 & 10 & 0 & 0 & 0 \\
\hline $\mathrm{J}$ & 25 & 24 & 24 & 14 & 2 & 1 & 11 & 0 & 0 & 0 \\
\hline Total (\%) & 242 & $192(79)$ & $173(71)$ & $72(30)$ & $24(10)$ & $57(24)$ & 43 (18) & 0 & 0 & 0 \\
\hline \multicolumn{11}{|l|}{2015} \\
\hline A & 15 & 14 & 10 & 6 & 1 & 3 & 0 & 0 & 0 & 0 \\
\hline B & 12 & 12 & 10 & 2 & 1 & 10 & 1 & 0 & 0 & 0 \\
\hline $\mathrm{E}$ & 25 & 11 & 9 & 5 & 1 & 5 & 1 & 1 & 1 & 1 \\
\hline $\mathrm{G}$ & 16 & 9 & 8 & 2 & 2 & 0 & 0 & 0 & 0 & 0 \\
\hline $\mathrm{K}$ & 25 & 18 & 13 & 3 & 5 & 9 & 6 & 0 & 0 & 1 \\
\hline $\mathrm{L}$ & 12 & 2 & 2 & 1 & 0 & 2 & 1 & 0 & 0 & 0 \\
\hline $\mathrm{M}$ & 9 & 5 & 5 & 5 & 1 & 0 & 0 & 0 & 0 & 0 \\
\hline $\mathrm{N}$ & 11 & 11 & 8 & 5 & 0 & 1 & 1 & 0 & 0 & 0 \\
\hline Total (\%) & 125 & $82(66)$ & $65(52)$ & $29(23)$ & $11(9)$ & $30(24)$ & $10(8)$ & $1(1)$ & $1(1)$ & $2(2)$ \\
\hline
\end{tabular}

a $\mathrm{LR}=$ low resistant, $\mathrm{MR}=$ moderately resistant, $\mathrm{R}=$ resistant, and $\mathrm{HR}=$ highly resistant.

b Year and location of fields sampled.

c Number of isolates.

Table 3. Phenotypic variation in fungicide resistance of Botrytis cinerea isolates from strawberry fields in Spain

\begin{tabular}{|c|c|c|c|c|c|c|c|c|c|c|c|c|c|c|c|c|c|c|c|c|c|}
\hline \multirow[b]{3}{*}{ Phenotype $^{\mathbf{a}}$} & \multirow[b]{3}{*}{$\mathbf{C C R}^{\mathrm{b}}$} & \multicolumn{18}{|c|}{ Number of isolates } & & \\
\hline & & \multicolumn{10}{|c|}{2014} & \multicolumn{8}{|c|}{2015} & \multicolumn{2}{|c|}{ Total $(\%)$} \\
\hline & & $\mathbf{A}$ & B & $\mathbf{C}$ & D & $\mathbf{E}$ & $\mathbf{F}$ & $\mathbf{G}$ & $\mathbf{H}$ & I & $\mathbf{J}$ & $\mathbf{A}$ & B & $\mathbf{E}$ & $\mathbf{G}$ & $\mathbf{K}$ & $\mathbf{L}$ & $\mathbf{M}$ & $\mathbf{N}$ & 2014 & 2015 \\
\hline None & 0 & 15 & 1 & 2 & 7 & 3 & 3 & 2 & 0 & 5 & 1 & 1 & 0 & 13 & 7 & 5 & 9 & 3 & 0 & $39(16.1)$ & $38(30.4)$ \\
\hline Py & 1 & 0 & 0 & 7 & 3 & 0 & 0 & 1 & 1 & 0 & 0 & 1 & 1 & 1 & 0 & 1 & 0 & 0 & 3 & $12(5.0)$ & $7(5.6)$ \\
\hline Cy & 1 & 2 & 0 & 0 & 2 & 0 & 0 & 0 & 2 & 2 & 0 & 0 & 0 & 0 & 0 & 1 & 0 & 1 & 0 & $8(3.3)$ & $2(1.6)$ \\
\hline $\mathrm{Fe}$ & 1 & 1 & 0 & 0 & 0 & 0 & 1 & 1 & 0 & 0 & 0 & 0 & 0 & 0 & 0 & 0 & 1 & 0 & 0 & $3(1.2)$ & $1(0.8)$ \\
\hline $\mathrm{Fl}$ & 1 & 0 & 0 & 0 & 0 & 0 & 0 & 0 & 0 & 0 & 0 & 0 & 0 & 0 & 0 & 1 & 0 & 0 & 0 & 0 & $1(0.8)$ \\
\hline Py-Bo & 2 & 3 & 7 & 6 & 4 & 6 & 2 & 2 & 3 & 1 & 5 & 4 & 1 & 3 & 5 & 3 & 0 & 0 & 2 & $39(16.1)$ & $18(14.4)$ \\
\hline Py-Cy & 2 & 1 & 0 & 1 & 0 & 1 & 0 & 0 & 0 & 0 & 0 & 2 & 0 & 1 & 1 & 1 & 0 & 0 & 0 & $3(1.2)$ & $5(4.0)$ \\
\hline $\mathrm{Py}-\mathrm{Fe}$ & 2 & 0 & 0 & 0 & 1 & 0 & 0 & 2 & 0 & 0 & 0 & 1 & 1 & 0 & 0 & 2 & 0 & 0 & 0 & $3(1.2)$ & $4(3.2)$ \\
\hline Py-Bo-Cy & 3 & 1 & 4 & 4 & 6 & 7 & 8 & 0 & 8 & 3 & 8 & 4 & 0 & 1 & 3 & 4 & 1 & 5 & 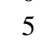 & $49(20.3)$ & $23(18.4)$ \\
\hline Py-Bo-Fe & 3 & 0 & 6 & 4 & 1 & 6 & 3 & 6 & 2 & 2 & 0 & 1 & 5 & 2 & 0 & 1 & 0 & 0 & 0 & $30(12.4)$ & $9(7.2)$ \\
\hline Py-Bo-Ip & 3 & 1 & 0 & 0 & 1 & 1 & 4 & 0 & 0 & 7 & 3 & 0 & 0 & 0 & 0 & 0 & 0 & 0 & 0 & $17(7.0)$ & 0 \\
\hline Cy-Ip-Fl & 3 & 0 & 0 & 0 & 0 & 0 & 0 & 0 & 0 & 0 & 0 & 0 & 0 & 1 & 0 & 0 & 0 & 0 & 0 & 0 & $1(0.8)$ \\
\hline Py-Bo-Cy-Fe & 4 & 3 & 6 & 1 & 0 & 0 & 1 & 2 & 0 & 0 & 0 & 1 & 3 & 2 & 0 & 0 & 0 & 0 & 0 & $13(5.4)$ & $6(4.8)$ \\
\hline Py-Bo-Сy-Ip & 4 & 0 & 0 & 1 & 0 & 0 & 1 & 0 & 2 & 2 & 7 & 0 & 0 & 0 & 0 & 0 & 0 & 0 & 0 & $13(5.4)$ & 0 \\
\hline Py-Bo-Fe-Ip & 4 & 0 & 0 & 1 & 2 & 0 & 1 & 2 & 0 & 0 & 0 & 0 & 1 & 0 & 0 & 4 & 1 & 0 & 1 & $6(2.5)$ & $7(5.6)$ \\
\hline Py-Bo-Cy-Fe-Ip & 5 & 0 & 0 & 2 & 0 & 1 & 0 & 1 & 1 & 1 & 1 & 0 & 0 & 0 & 0 & 2 & 0 & 0 & 0 & $7(2.9)$ & $2(1.6)$ \\
\hline Py-Bo-Cy-Fe-Ip-Fl & 6 & 0 & 0 & 0 & 0 & 0 & 0 & 0 & 0 & 0 & 0 & 0 & 0 & 1 & 0 & 0 & 0 & 0 & 0 & 0 & $1(0.8)$ \\
\hline Total & $\ldots$ & 27 & 24 & 29 & 27 & 25 & 24 & 19 & 19 & 23 & 25 & 15 & 12 & 25 & 16 & 25 & 12 & 9 & 11 & $242(100.0)$ & $125(100.0)$ \\
\hline
\end{tabular}

a Phenotype resistance to fungicides $\mathrm{Py}=$ Pyraclostrobin, $\mathrm{Bo}=$ Boscalid, $\mathrm{Cy}=$ Cyprodinil, $\mathrm{Ip}=$ Iprodione, $\mathrm{Fe}=\mathrm{Fenhexamid}$, and $\mathrm{Fl}=\mathrm{Fludioxonil}$.

${ }^{\mathrm{b}}$ Chemical class resistance. 
was found at all of the farms except for farms G and M in 2015. Resistance to iprodione was found at all of the farms except for farm B in 2014 and farms A, G, and M in 2015. Resistance to fludioxonil was only found at farms E and $\mathrm{K}$ in 2015 (Table 2).

Multifungicide resistance of the $B$. cinerea field isolates. The majority of the $B$. cinerea isolates from the strawberry fruit samples had resistance to one or more of the fungicides. In 2014, isolates resistant to one (9.5\%), two (18.5\%), three (39.7\%), four (13.3\%), or five (2.9\%) chemical classes of fungicides were observed (Table 3). In 2015 , the distribution of multifungicide-resistant isolates was 8.8 , $21.6,26.4,10.4$, and $1.6 \%$, respectively (Table 3 ). Only a single isolate was found to be resistant to all fungicides $(0.8 \%)$ in 2015 . The frequency of isolates with resistance to three or more fungicides was highest in fields $\mathrm{J}$ (76\%) and F (75\%) in 2014 and field B (75\%) in 2015 (Table 3; Fig. 2). The frequency of multifungicide-resistant isolates was lowest in field A (18\%) in 2014 and the organic field L (17\%) in 2015 (Table 3; Fig. 2). There seemed to be a dramatic reduction of isolates that were sensitive to all classes of fungicides in strawberry field A from 2014 to 2015 (Fig. 2).

Among the isolates resistant to two fungicides, 57 were resistant to pyraclostrobin and boscalid, 8 were resistant to pyraclostrobin and cyprodinil, and 7 were resistant to pyraclostrobin and fenhexamid (Table 3). Among the isolates resistant to three fungicides, 72, 39, and 17 were resistant to pyraclostrobin, boscalid, and cyprodinil + fenhexamid + iprodione, respectively. Only one isolate was resistant to cyprodinil, iprodione, and fludioxonil (Table 3). The majority of the isolates resistant to four fungicides (19 in total; Table 3 ) were resistant to pyraclostrobin, boscalid, cyprodinil, and fenhexamid followed by isolates with resistance to pyraclostrobin, boscalid, cyprodinil, and iprodione (13 isolates; Table 3 ), and isolates resistant to pyraclostrobin, boscalid, fenhexamid, and iprodione (13 isolates; Table 3).

Mutations in bos1, cytb, erg27, and $\boldsymbol{s d h B}$ genes. The presence or absence of mutations in genes encoding target proteins for iprodione, pyraclostrobin, fenhexamid, and boscalid were determined for a set of isolates representative of all of the fields examined. For iprodione, the bos 1 gene from $1 \mathrm{MR}, 14 \mathrm{LR}$, and $16 \mathrm{~S}$ isolates was sequenced, and sequence analysis revealed nucleotide variations in the LR and MR isolates but not in the $\mathrm{S}$ isolates. The LR isolates had the amino acid alteration I365S (six isolates) or I365 N (eight isolates). The iprodione MR isolate had the mutation I365S (Table 4). For pyraclostrobin, 41 isolates (19 S and $22 \mathrm{HR}$ ) were analyzed. All 22 isolates that were HR to pyraclostrobin had the G143A mutation in the $c y t b$ gene (Table 4); however, for the $\mathrm{S}$ isolates, two genotypes were observed. These $\mathrm{S}$ genotypes were differentiated by the absence ( 9 isolates) or presence (10 isolates) of the Bcbi-143/144 intron after G143. For fenhexamid, the sequence analysis of the $\operatorname{erg} 27$ gene revealed that 15 fenhexamid-S isolates had only silent mutations. However, of the 16 fenhexamid-HR isolates studied, 14 isolates possessed the F412S mutation, 1 isolate had the F412I substitution, and 1 isolate had the amino acid change F412V (Table 4). In regards to boscalid sensitivity, the $s d h B$ gene of $34 \mathrm{~B}$. cinerea isolates was sequenced ( $18 \mathrm{~S}$ and $16 \mathrm{R}$ ). The sequence analysis revealed that $13 \mathrm{R}$ isolates had the H272R mutation and $3 \mathrm{R}$ isolates had the substitution H272Y (Table 4).

\section{Discussion}

This study provides information on the occurrence, distribution, and molecular basis of resistance to six fungicides belonging to different chemical groups in $B$. cinerea populations from commercial strawberry fields in Spain. Fungicide resistance was widespread and found in every commercial field for the majority of the fungicides studied. Although at lower frequencies than the rest of the commercial farms, fungicide-resistant isolates were even recovered from location L, which was an organic farm that, according to the producer, had not been sprayed with single-site fungicides. However, the migration of the resistant isolates into this field was very likely because there were several conventional strawberry fields in the surrounding landscape. Alternatively, resistant isolates may have been introduced into this field from latent infections in leaf or crown tissue of the transplants that occurred in the nursery.

$B$. cinerea isolates with resistance to QoI and SDHI fungicides was common in all locations that were extensively treated with the commercial mixture of boscalid and pyraclostrobin, Signum (BASF Española S.A.). The high frequencies of resistance to both pyraclostrobin and boscalid observed in this study could be explained by the fact that Signum is used to control other strawberry diseases such as powdery mildew and Sclerotinia crown and fruit rot. In addition to pyraclostrobin, other QoI fungicides such as azoxystrobin (Ortiva; Syngenta España, S.A.), kresoxim-methyl (Stroby WB; Discus),

Table 4. Amino acid substitutions in target proteins in Botrytis cinerea isolates resistant to boscalid, fenhexamid, iprodione, and pyraclostrobin

\begin{tabular}{|c|c|c|c|c|c|c|c|c|}
\hline & \multicolumn{8}{|c|}{ Amino acid substitutions in target proteins } \\
\hline & \multicolumn{2}{|c|}{$\operatorname{SdhB}(n=16)$} & \multicolumn{3}{|c|}{$\operatorname{Erg} 27(n=16)$} & \multicolumn{2}{|c|}{$\operatorname{Bos} 1(n=15)$} & $\begin{array}{c}\text { Cytb } \\
(n=22)\end{array}$ \\
\hline & $\overline{H 272 R}$ & $\overline{\mathrm{H} 272 \mathrm{Y}}$ & F412I & F412S & $\mathbf{F 4 1 2 V}$ & $\overline{1365 N}$ & $\mathbf{I 3 6 5 S}$ & $\overline{\text { G143A }}$ \\
\hline & 13 & 3 & 1 & 14 & 1 & 8 & 7 & 22 \\
\hline Percent & 81 & 19 & 6 & 88 & 6 & 53 & 47 & 100 \\
\hline
\end{tabular}

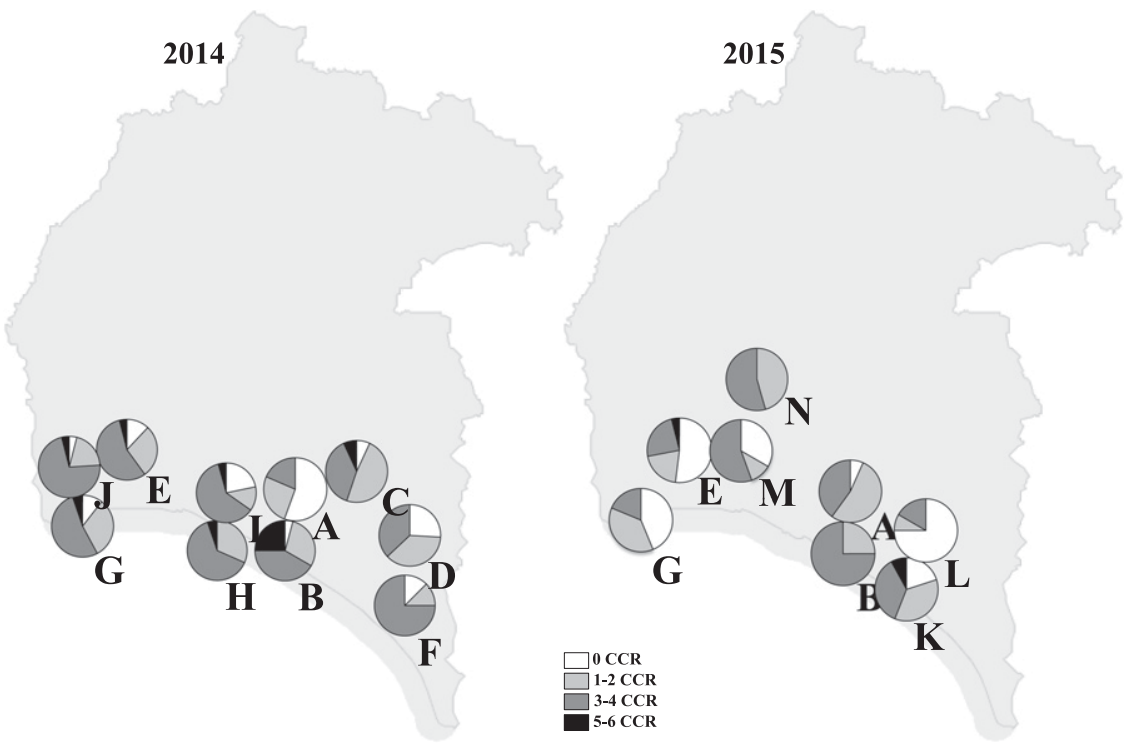

Fig. 2. Occurrence and prevalence of single chemical class resistance (CCR) in Botrytis cinerea isolates collected from 14 locations during 2014 and 2015 growing seasons. 
and trifloxystrobin (Flint; Scorpio) as single formulations, or in premixes azoxystrobin + difenoconazole (Ortiva Top; Syngenta España, S.A.) represent the mainstay of powdery mildew (caused by Podosphaera aphanis) control in Spanish strawberry fields and likely contributed to the buildup of QoI resistance in B. cinerea. Resistance to QoI and SDHI has previously been reported for $B$. cinerea in strawberry and other crops worldwide (Amiri et al. 2013; Bardas et al. 2010; Fernández-Ortuño et al. 2012; Kim and Xiao 2010; Konstantinou et al. 2015; Leroux et al. 2010; Veloukas et al. 2014). The overall frequency of resistance observed for SDHI in this study is in agreement with those of previous studies from strawberry fields in Greece (Konstantinou et al. 2015) and the United States (Fernández-Ortuño et al. 2012), which described resistance frequencies of 54.9 to 77.1 , and $61.5 \%$, respectively. The overall frequency of resistance observed for QoI in the present work is also in agreement with previous reports from strawberry fields in Germany (69\%; Grabke and Stammler 2015), Greece (67.2 to 86.2\%; Konstantinou et al. 2015), Italy (66.7\% in 2011; De Miccolis Angelini et al. 2014), and the United States (66.7\%; Fernández-Ortuño et al. 2012) and from other small fruit crops in Germany (76.8\%; Weber 2011).

This study also documents fairly widespread resistance to the AP fungicide cyprodinil and very low frequencies of resistance to the PP fungicide fludioxonil, which are both active ingredients of the prepacked mixture Switch (Syngenta España, S.A.). Spanish strawberry growers have been using this combination frequently since 2008 (Anonymous 2008, 2015). In addition, some strawberry producers indicated that they frequently use the AP fungicide pyrimethanil Pyrus 400SC (Arysta Lifescience Benelux SPRL) and Scala (BASF Española S.A.). The continuous use of products that contain AP may explain why the overall resistant frequency (37\%) obtained in this study for cyprodinil is higher compared with previous studies (Diánez et al. 2002). Similar results following multiple applications of AP fungicides during several years were observed in $B$. cinerea field isolates from Chilean vineyards (Latorre et al. 2002) and vegetable crops from Greece (Myresiotis et al. 2007). The frequencies AP resistance observed in our study are in line with findings in studies in other systems (Fernández-Ortuño et al. 2013; Latorre et al. 2002; Lu et al. 2016; Panebianco et al. 2015). Fludioxonil-resistant isolates were rarely observed in this study and only three isolates were resistant to this fungicide. This fungicide is an attractive tool for resistance management programs worldwide because resistance to this fungicide in fungal plant pathogens is rarely observed (De Miccolis Angelini et al. 2014; Fernández-Ortuño et al. 2014; Kretschmer et al. 2009; Leroch et al. 2013; Li et al. 2014), which may be due to fitness penalties (Li and Xiao 2008; Ziogas et al. 2005).

Resistance to the KRI fungicide fenhexamid was found at moderate levels in the majority of the locations surveyed. Although this fungicide is one of the most frequently used fungicides for gray mold control in commercial fields in Spain over the last 5 years (Anonymous 2010, 2015), growers still find that it provides acceptable levels of control. In our study, strawberry field $\mathrm{G}$ had the highest frequency of resistant isolates $(73.7 \%)$ in 2014. It is known that this producer used the KRI commercial fungicide Teldor more frequently than others, which could explain the prevalence of fenhexamid-resistant isolates. Interestingly, fenhexamid resistance was not observed on this farm in 2015. The absence of fenhexamid resistance could be explained by intense planting renovation (land plowed and soil disinfected) carried out at this location in summer 2014. Overall, the frequency of fenhexamid-resistant isolates obtained in this study ( $24 \%$ both years) was higher than those observed in North and South Carolina (17\%; Grabke et al. 2013); and lower than the ones described from strawberry fields in California (38\%; Mercier et al. 2010), Florida (44.4\%; Amiri et al. 2013), and Germany (45\%; Weber 2011).

The present study indicates that resistance to the DC fungicide iprodione is widely distributed in the Spanish strawberry fields but low in prevalence. The isolates with LR to iprodione (overall $14.4 \%$ ) were found in 90 and $62.5 \%$ of the fields analyzed in 2014 and 2015, respectively. Only one isolate, collected in 2015, was categorized as MR. Resistance to the DC fungicides was detected previously in B. cinerea Spanish strawberry isolates, with $44 \%$ of the
36 isolates having resistance to iprodione (Diánez et al. 2002). The relative low frequency of resistance observed in our study may be due to the limited exposure of the $B$. cinerea isolates in strawberry fields to DC over the last few years. This lack of DC use is coincident with the introduction of new site-specific fungicides for gray mold control. Grabke et al. (2014) reported a similar frequency of resistance to iprodione in the United States that could be due to the limited use of DC fungicides after 1998. Such information suggests that iprodione could be used as part of an integrated management programs for gray mold control in Spain.

Multifungicide-resistant isolates were commonly observed in B. cinerea populations collected from commercial strawberry fields in Spain. The majority of these isolates were resistant to pyraclostrobin, pyraclostrobin + boscalid, pyraclostrobin + boscalid + cyprodinil, and pyraclostrobin + boscalid + cyprodinil + fenhexamid. Recently, $\mathrm{Li}$ et al. (2014) described a model that revealed that multifungicide resistance patterns did not evolve randomly in the strawberry populations, and the most prevalent profiles models were described in this study. The overall frequency of the $B$. cinerea isolates with resistance to two or more fungicides in the fields studied $(69.7 \%)$ was very similar to the frequencies ( 70 and $60 \%$ ) reported from strawberry fields in Florida and seven southern U.S. states, respectively (Amiri et al. 2013; Fernández-Ortuño et al. 2014).

Consistent with results published previously, resistance to boscalid, fenhexamid, iprodione, and pyraclostrobin was associated with target site mutations. The predominant amino acid substitutions in the SdhB protein in our collection were $\mathrm{H} 272 \mathrm{R}$ and $\mathrm{H} 272 \mathrm{Y}$. Both amino acid changes were reported in previous studies on $B$. cinerea in small fruit crops, with the H272R being the most widespread substitution (Fernández-Ortuño et al. 2012; Li et al. 2014). The predominant amino acid substitution in Erg27 conferring resistance to fenhexamid in Spain was F412S. This substitution was also the most prevalent observed in previous investigations of $B$. cinerea from blackberry and strawberry fields in the United States (Grabke et al. 2013; Li et al. 2014). In regards to iprodione resistance, the amino acid substitution I365S in Bos1 was associated with the LR and MR phenotypes; however, the amino acid substitution I365 N was also linked with the LR phenotype. These amino acid changes were also correlated with DC resistance in previous studies (Grabke et al. 2014; Ma et al. 2007). Finally, all the pyraclostrobin-HR isolates had the Cytb G143A mutation, which is the most frequently described amino acid substitution associated with resistance to QoI fungicides (Fernández-Ortuño et al. 2008).

In summary, the results obtained in this study indicate widespread single-site fungicide resistance to pyraclostrobin, boscalid, cyprodinil, fenhexamid, and iprodione. However, the frequency of isolates resistant to fludioxonil was low. Our results highlight the need for resistance-monitoring programs in Spain to help growers determine location-specific resistance profiles, identify weaknesses in their spray programs, and develop farm-specific chemical management strategies, as previously described (Schnabel et al. 2015).

\section{Acknowledgments}

D. Fernández-Ortuño received funding from the Marie Curie COFUND programme U-Mobility, co-financed by the University of Malaga, the European Commission FP7 under GA Number 246550, Ministerio de Economía y Competitividad (COFUND2013-40259), and Fundación General CSIC (Programa ComFuturo). We thank L. Miranda Enamorado (IFAPA Centro Las Torres-Tomejil) for helping us collect strawberry isolates and J. M. Pulido and R. Cerezo Arrabal for their technical support.

\section{Literature Cited}

Amiri, A., Heath, S. M., and Peres, N. A. 2013. Phenotypic characterization of multifungicide resistance in Botrytis cinerea isolates from strawberry fields in Florida. Plant Dis. 97:393-401.

Anonymous. 2008. Balance fitosanitario del cultivo de la fresa campaña 2008. Red de alerta e información fitosanitaria R.A.I.F. Consejería de Agricultura y Pesca. Junta de Andalucía. Online: http://www.juntadeandalucia.es/agriculturaypesca/ portal/export/sites/default/comun/galerias/galeriaDescargas/minisites/raif/balances/ 2008/huelva/Informe_EspecialInteres_Fresa.pdf

Anonymous. 2010. Balance fitosanitario del cultivo de la fresa campaña 2010. Red de alerta e información fitosanitaria R.A.I.F. Consejería de Agricultura y Pesca. Junta de Andalucía. Online: http://www.juntadeandalucia.es/agriculturaypesca/ raif/informes/informes_balances/2010/index.html 
Anonymous. 2015. Balance fitosanitario del cultivo de la fresa campaña 20142015. Red de alerta e información fitosanitaria R.A.I.F. Consejería de Agricultura, Pesca y Desarrollo Rural. Online publication. Junta de Andalucía, Spain. http://www.juntadeandalucia.es/agriculturaypesca/portal/export/sites/ default/comun/galerias/galeriaDescargas/minisites/raif/balances/2015/huelva/ Informe EspecialInteres Fresa.pdf

Bardas, G. A., Veloukas, T., Koutita, O., and Karaoglanidis, G. S. 2010. Multiple resistance of Botrytis cinerea from kiwifruit to SDHIs, QoIs and fungicides of other chemical groups. Pest Manage. Sci. 66:967-973.

Baroffio, C. A., Siegfried, W., and Hilber, U. W. 2003. Long-term monitoring for resistance of Botrytis cinerea to anilinopyrimidine, phenylpyrrole, and hydroxyanilide fungicide in Switzerland. Plant Dis. 87:662-666.

Bulger, M. A., Ellis, M. A., and Madden, L. V. 1987. Influence of temperature and wetness duration on infection of strawberry flowers by Botrytis cinerea and disease incidence of fruit originating from infected flowers. Phytopathology 77:1225-1230.

Chi, M. H., Park, S. Y., and Lee, Y. H. 2009. A quick and safe method for fungal DNA extraction. Plant Pathol. J. 25:108-111.

De Miccolis Angelini, R. M., Rotolo, C., Masiello, M., Gerin, D., Pollastro, S., and Faretra, F. 2014. Occurrence of fungicide resistance in populations of Botryotinia fuckeliana (Botrytis cinerea) on table grape and strawberry in southern Italy. Pest Manage. Sci. 70:1785-1796.

Diánez, F., Santos, M., Blanco, R., and Tello, J. C. 2002. Fungicide resistance in Botrytis cinerea isolates from strawberry crops in Huelva (southwestern Spain). Phytoparasitica 30:529-534.

Fernández-Ortuño, D., Chen, F., and Schnabel, G. 2012. Resistance to pyraclostrobin and boscalid in Botrytis cinerea isolates from strawberry fields in the Carolinas. Plant Dis. 96:1198-1203.

Fernández-Ortuño, D., Chen, F., and Schnabel, G. 2013. Resistance to cyprodinil and lack of fludioxonil resistance in Botrytis cinerea isolates from strawberry in North and South Carolina. Plant Dis. 97:81-85.

Fernández-Ortuño, D., Grabke, A., Bryson, P. K., Amiri, A., Peres, N. A., and Schnabel, G. 2014. Fungicide resistance profiles in Botrytis cinerea from strawberry fields of seven southern U.S. states. Plant Dis. 98:825-833.

Fernández-Ortuño, D., Torés, J. A., de Vicente, A., and Pérez-García, A. 2008. Mechanisms of resistance to QoI fungicides in phytopathogenic fungi. Int. Microbiol. 11:1-9.

Grabke, A., Fernández-Ortuño, D., Amiri, A., Li, X. P., Peres, N. A., Smith, P., and Schnabel, G. 2014. Characterization of iprodione resistance in Botrytis cinerea from strawberry and blackberry. Phytopathology 104:396-402.

Grabke, A., Fernández-Ortuño, D., and Schnabel, G. 2013. Fenhexamid resistance in Botrytis cinerea from strawberry fields in the Carolinas is associated with four target gene mutations. Plant Dis. 97:271-276.

Grabke, A., and Stammler, G. 2015. A Botrytis cinerea population from a single strawberry field in Germany has a complex fungicide resistance pattern. Plant Dis. 99:1078-1086.

Jarvis, W. R. 1977. Botryiotinia and Botrytis Species: Taxonomy, Physiology, and Pathogenicity. Monograph Number 15. Research Branch Canada Department of Agriculture, Harrow, Ontario, Canada.

Kim, Y. K., and Xiao, C. L. 2010. Resistance to pyraclostrobin and boscalid in populations of Botrytis cinerea from stored apples in Washington State. Plant Dis. 94:604-612

Konstantinou, S., Veloukas, T., Leroch, M., Menexes, G., Hahn, M., and Karaoglanidis, G. 2015. Population structure, fungicide resistance profile, and $s d h B$ mutation frequency of Botrytis cinerea from strawberry and greenhousegrown tomato in Greece. Plant Dis. 99:240-248.

Kretschmer, M., Leroch, M., Mosbach, A., Walker, A.-S., Fillinger, S., Mernke, D., Schoonbeek, H., Pradier, J.-M., Leroux, P., and De Waard, M. A. 2009. Fungicide-driven evolution and molecular basis of multidrug resistance in field populations of the grey mould fungus Botrytis cinerea. PLoS Pathog. 5:e1000696.
Latorre, B. A., Spadaro, I., and Rioja, M. E. 2002. Occurrence of resistant strains of Botrytis cinerea to anilinopyrimidine fungicides in table grapes in Chile. Crop Prot. 21:957-961.

Leroch, M., Plesken, C., Weber, R. W. S., Kauff, F., Scalliet, G., and Hahn, M 2013. Gray mold populations in German strawberry fields show multiple fungicide resistance and are dominated by a novel clade close to Botrytis cinerea. Appl. Environ. Microbiol. 79:159-67.

Leroux, P., Gredt, M., Leroch, M., and Walker, A. S. 2010. Exploring mechanisms of resistance to respiratory inhibitors in field strains of Botrytis cinerea, the causal agent of gray mold. Appl. Environ. Microbiol. 76:6615-6630.

Li, H. X., and Xiao, C. L. 2008. Characterization of fludioxonil-resistant and pyrimethanil-resistant phenotypes of Penicillium expansum from apple. Phytopathology 98:427-435.

Li, X. P., Fernández-Ortuño, D., Chen, S., Grabke, A., Luo, C. X., and Schnabel, G. 2014. Location-specific fungicide resistance profiles and evidence for stepwise accumulation of resistance in Botrytis cinerea. Plant Dis. 98:1066-1074.

Lu, X. H., Jiao, X. L., Hao, J. J., Chen, A. J., and Gao, W. W. 2016. Characterization of resistance to multiple fungicides in Botrytis cinerea populations from Asian ginseng in northeastern China. Eur. J. Plant Pathol. 144:467-476.

Ma, Z., Yan, L., Luo, Y., and Michailides, T. J. 2007. Sequence variation in the two-component histidine kinase gene of Botrytis cinerea associated with resistance to dicarboximide fungicides. Pestic. Biochem. Physiol. 88: 300-306.

Mercier, J., Kong, M., and Cook, J. 2010. Fungicide resistance among Botrytis cinerea isolates from California strawberry fields. Online publication. Plant Health Prog. doi:10.1094/PHP-2010-0806-01-RS

Myresiotis, C. K., Karaoglanidis, G. S., and Tzavella-Klonari, K. 2007. Resistance of Botrytis cinerea isolates from vegetable crops to anilinopyrimidine, phenylpyrrole, hydroxyanilide, benzimidazole, and dicarboximide fungicides. Plant Dis. 91:407-413.

Panebianco, A., Castello, I., Cirvilleri, G., Perrone, G., Epifani, F., Ferrara, M., Polizzi, G., Waters, D. R., and Vitale, A. 2015. Detection of Botrytis cinerea field isolates with multiple fungicide resistance from table grape in Sicily. Crop Prot. 77:65-73.

Raposo, R., Delcan, J., Gomez, V., and Melgarejo, P. 1996. Distribution and fitness of isolates of Botrytis cinerea with multiple fungicide resistance in Spanish greenhouses. Plant Pathol. 45:497-505.

Rodríguez, A., Acosta, A., and Rodríguez, C. 2014. Fungicide resistance of Botrytis cinerea in tomato greenhouses in the Canary Islands and effectiveness of non-chemical treatments against gray mold. World J. Microbiol. Biotechnol. 30:2397-2406.

Schnabel, G., Hu, M., and Fernández-Ortuño, D. 2015. Monitoring resistance by bioassay: Relating results to field use using culturing methods. Pages 281-293 in: Fungicide Resistance in Plant Pathogens, Principles and a Guide to Practical Management, part III. H. Ishii and D. W. Hollomon, eds. Springer Japan, Tokyo.

Staats, M., van Baarlen, P., and van Kan, J. A. L. 2005. Molecular phylogeny of the plant pathogenic genus Botrytis and the evolution of host specificity. Mol. Biol. Evol. 22:333-346.

Veloukas, T., Kalogeropoulou, P., Markoglou, A. N., and Karaoglanidis, G. S 2014. Fitness and competitive ability of Botrytis cinerea field isolates with dual resistance to SDHI and QoI fungicides, associated with several $s d h B$ and the cytb G143A mutations. Phytopathology 104:347-356.

Weber, R. W. S. 2011. Resistance of Botrytis cinerea to multiple fungicides in Northern German small-fruit production. Plant Dis. 95:1263-1269.

Weber, R. W. S., and Hahn, M. 2011. A rapid and simple method for determining fungicide resistance in Botrytis. J. Plant Dis. Prot. 118:17-25.

Ziogas, B. N., Markoglou, A. N., and Spyropoulou, V. 2005. Effect of phenylpyrrole-resistance mutations on ecological fitness of Botrytis cinerea and their genetical basis in Ustilago maydis. Eur. J. Plant Pathol. 113:83-100. 